DOI: $10.21802 /$ artm.2020.3.15.144.

УДК 616.345-006.6:616.34-007.272:616.345/.348-089.86

\title{
ГЕМІКОЛЕКТОМІЯ ПРИ ОБСТРУКТИВНОМУ РАКУ ПРАВОЇ ПОЛОВИНИ ОБОДОВОї КИШКИ
}

\author{
В.І. Русин, С.М. Чобей, О.О. Дутко \\ Ужгородський національний університет, медичний факультет, кафедра хірургічних хвороб, \\ м. Ужгород, Україна, \\ ORCID ID: 0000-0001-5688-9951, ORCID ID: 0000-0002-1231-8169, ORCID ID: 0000-0002-4063-8194, \\ e-mail:dutko.sasha93@gmail.com
}

Резюме. Мета дослідження. Для покращення результатів лікування хворих на обструктивний рак правих відділів товстої кишки розпрацювати та втілити в клінічну практику інвагінаційний ілеотрансверзоанастомоз.

Матеріали та методи. У хірургічному відділенні №2 КНП «Обласна клінічна лікарня ім. Андрія Новака» 3ОР за 2015-2019pр. нами проліковано 94 хворих на обструктивний рак правих відділів товстої кишки. У 39 хворих виконана правобічна геміколектомія з двохрядним ілео-трансверзоанастомозом, у 55 - по безконтактній ізолюючій методиці з інвагінаційним ілео-трансверзоанастомозом у нашій модифікації.

Результати дослідження. При використанні двохрядного шва у 2 пацієнтів наступила неспроможність анастомозу. При формуванні інвагінаційного ілео-трансверзоанастомозу ускладнень не було. На контрольній фіброколоноскопії інвагінаційна кукса здухвинної кишки перистальтувала у просвіт поперечно-ободової кишки. На іригоскопії рефлюкс-ентериту не було. Отже, можна стверджувати, що інвагінаційні ілеотрансверзоанастомози переймають на себе функцію ілеоцекального клапану. При визначенні меж резекції товстої кишки важливо враховувати локалізацію їі сфінктерів. При формуванні анастомозів будь-яка перепона для пересування кишкового вмісту може призвести до підйому внутрішньокишкового тиску, що може зіграти роль в розвитку неспроможності анастомозу. Інвагінаційний анастомоз може створюватись у будь-якому відділі ободової кишки.

Висновки. Запропонований нами інвагінаційний однорядний ілео-трансверзоанастомоз надійно відновлює прохідність кишківника, перешкоджає розвитку рефлюкс-ентериту, простий у виконанні і може бути рекомендованим до практичного використання при обструктивному раку ободової кишки.

Ключові слова: ілео-трансверзоанастомоз, рак товстої кишки, кишкова непрохідність, геміколектомія.

Вступ. Захворюваність на рак товстої кишки як у світі, так і в Україні за останні десятиріччя постійно зростає і вийшла на третє місце в структурі онкологічних захворювань. [1-3]. У розвинених країнах, таких як США, Японії, Німеччині, на 100 тис. населення реєструють 40 випадків колоректального раку у чоловіків і $30-$ у жінок. У країна Африки, Південної Америки, Азії - відповідно 5-10 і 2-3. В Україні - 34,9 та 26,4 відповідно [3].

Кількість ускладнених форм колоректального раку у вигляді гострої кишкової непрохідності практично стабільна і трапляється у 20-40\% усіх хворих, де більшість із них поступають в ургентному порядку в загальнохірургічні стаціонари. Післяопераційна летальність за таких обставин сягає до 20\% на фоні порушень моторно-евакуаторної функції і внутрішньокишкової гіпертензії, яка призводить до неспроможності кишкових анастомозів, що зустрічається у 3-16\% після планових операцій та 3-68\% після лікування ускладнених форм [3-5]. Незважаючи на загальний прогрес у галузі медицини, застосування найновіших фармакологічних препаратів, удосконалення хірургічної техніки та методик інтенсивної терапії, проблема обтураційної кишкової непрохідності не зникла, але і надалі залишається найчастішим ускладненням раку товстої кишки [4,6-8].
Обгрунтування дослідження. Частка пацієнтів 3 локалізацією пухлини в ілеоцекальному куті поступає 3 неспроможністю Баугінієвої заслінки товстокишковий вміст закидується в здухвинну кишку, що призводить до термінального рефлюкс-ілеїту. В таких випадках межі резекції необхідно розширювати, так як змінена кишка - не кращий матеріал для створення анастомозу [3]. Важливим продовжує залишатись вибір місця пересічення поперечноободової кишки, де хірург зобов'язаний переконатись в достатньому кровопостачанні кукси.

Відповідальним моментом, який безпосередньо впливає на результат хірургічного втручання, $\epsilon$ формування ілео-трансверзоанастомозу та техніка створення кишкового шва. Незважаючи на десятки способів створення міжкишкових анастомозів, проблеми відновлення прохідності пов'язані насамперед iз недосконалістю техніки створення анастомозу та кишкового шва $[9,10]$.

Мета дослідження. Для покращення результатів лікування хворих на обструктивний рак правих відділів товстої кишки розпрацювати та втілити в клінічну практику інвагінаційний ілеотрансверзоанастомоз.

Матеріали і методи дослідження. В хірургічному відділенні №2 КНП «Обласна клінічна лікарня 
ім. Андрія Новака» 3ОР у період 2015-2019pр. нами проліковано 94 хворих на обструктивний рак ободової кишки (ОРОК) $з$ приводу раку правих відділів товстої кишки. У 39 хворих контрольної групи виконана традиційна правобічна геміколектомія 3 двохрядним ілео-трансверзоанастомозом по типу «бік в бік», у 55 основної групи - по безконтактній ізолюючій методиці 3 інвагінаційним однорядним ілеотрансверзоанастомозом в нашій модифікації. Основне поняття вказаної методики - від самого початку втручання забезпечити максимально можливу блокаду злоякісної пухлини, перекривши основні шляхи метастазування - по стінці кишки, по іiі просвіту, гематогенний, лімфогенний і контактний.

Серед пацієнтів чоловіків було 51 (54\%), а жінок відповідно 43 (46\%). Усі пацієнти були віком від 60 до 75 років, середній вік складав $67 \pm 4,0$ р. у жінок та $67 \pm 4,8$ р. у чоловіків.

у пацієнтів основної групи ілеотрансверзоанастомоз (патент України №98084582) [11] виконували наступним чином. При накладанні анастомозу, після резекції тонкої кишки на останню накладають кисет на довгій лігатурі по самому краю кишки. Лігатура утримується під натягом, при цьому виключається контамінація органів черевної порожнини кишковим вмістом тому, що лігатура у вигляді зашморгу перекриває просвіт кишки. Вільний кінець тонкої кишки має бути звільнений від брижі на 2-3 см. Далі вільний кінець тонкої кишки пришивається до товстої кишки по типу «кінець в бік» по всій своїй ширині під tenia libera однорядним серозно-м'язовим швом. Після цього товста кишка розрізається по tenia libera на ширину діаметра кишки. Через цей отвір довгою (великою) голкою роблять прокол по tenia libera i проводять лігатуру кисету накладеного на тонку кишку, кінець тонкої кишки занурюється в просвіт поперечно-ободової кишки, при цьому асистент утримує лігатуру в натягнутому стані. За цим накладають ряд серозно-м'язових швів на передню частину анастомозу. У кінці відкривають просвіт тонкої кишки шляхом пересічення одного 3 кінців лігатури-трималки біля tenia libera товстої кишки та видаленням за її другий кінець (рис. 1).

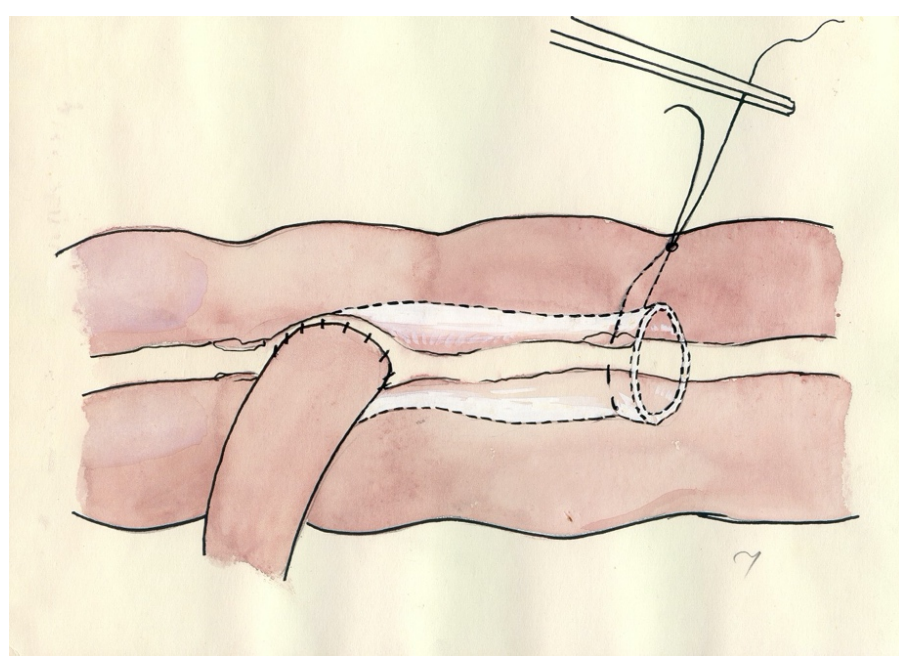

Рис. 1. Схема створеного ілеотрансверзоанастомозу. Відкриття просвіту тонкої кишки в просвіті товстої шляхом витягання лігатури кисету за один їі кінець

Таким чином прохідність створеного ілеотрансверзоанастомозу відновлюється після видалення лігатури кисетного шва тонкої кишки.

У контрольній групі формували традиційний ілео-трансверзоанастомоз по типу «бік в бік» із накладанням двохрядного шва без інвагінації вільного відділу тонкої кишки у просвіт товстої кишки.

Діагностична програма усіх пацієнтів як основної, так і контрольної груп, складалася з загальноклінічних аналізів крові та сечі, біохімічних показників крові та показників коагулограми, ультразвукового обстеження органів черевної порожнини, фіброколоноскопії з біопсією пухлини у разі відсутності ознак гострої кишкової непрохідності, комп'ютерної томографії органів черевної і грудної порожнин та органів малого тазу з внутрішньовенним контрастуванням.

По стандарту проводилася контрольна фіброколоноскопія та іригографія через 6 місяців після оперативного втручання.

Для статистичного аналізу та порівняння груп пацієнтів було використано критерій хі-квадрат.
При цьому відмінність у досліджуваній та контрольній групах $€$ статистично значимою при значенні $\mathrm{p}<0,05$. Для статистичної обробки даних використовувалась комп'ютерна програма јаmovi [12].

Результати дослідження. Локалізація пухлин правої половини ободової кишки у всіх хворих була наступною: сліпа кишка у 42 хворих (44\%), висхідна частина ободової кишки - у 21 хворого (22\%) та печінковий кут ободової кишки - у 31 хворого (34\%). Віддалених метастазів у жодного хворого не було виявлено. Результати патогістологічного дослідження виявили аденокарциному різного ступеня диференціювання (G 1-3).

При традиційній правобічній геміколектомії 3 двохрядним ручним швом по типу «бік в бік» у 2 пацієнтів $(5,1 \%)$ наступила неспроможність анастомозу з розвитком перитоніту. У цих хворих виконувалась релапаротомія з ліквідацією неспроможності та формуванням ілеостоми. При формуванні інвагінаційного ілео-трансверзоанастомозу по типу «кінець в бік» неспроможності анастомозу ми не спостерігали в жодного пацієнта (табл. 1). 
Таблиця 1

Післяопераційні ускладнення у хворих основної та контрольної груп

\begin{tabular}{|c|c|c|c|}
\hline Ускладнення & $\begin{array}{c}\text { Однорядний } \\
\text { інвагінаційний } \\
\text { анастомоз }\end{array}$ & $\begin{array}{c}\text { Двохрядний ручний } \\
\text { анастомоз }\end{array}$ & р-значення \\
\cline { 1 - 2 } Без ускладнень & $55(100 \%)$ & $37(94,9 \%)$ & $\mathrm{p}<0,05$ \\
\hline Неспроможність анастомозу & 0 & $2(5,1 \%)$ & \\
\hline Всього & 55 & 39 & \\
\hline
\end{tabular}

У післяопераційному періоді всі хворі отримували стандартне консервативне лікування.

Контрольну фіброколоноскопію та іригографію після оперативного втручання пройшла близько половина пацієнтів (29 хворих основної групи та 20 контрольної).

На контрольній фіброколоноскопії у пацієнтів основної групи через 6 місяців видно, що інвагінаційна кукса здухвинної кишки по околу свого діаметру вільно перистальтувала у просвіт поперечноободової кишки (рис. 2).

На контрольній іригографії у основної групи через 6 місяців після оперативного втручання рефлюкс-ентериту не спостерігали (рис. 3), про що свідчила відсутність закидування контрастної речовини 3 товстої кишки у тонку кишку. На відміну від основної групи, у контрольній групі у більшої частини пацієнтів відмічалося закидування контрастної речовини у просвіт тонкої кишки (25\% хворих контрольної групи).

Деяка частина хворих контрольної групи, у яких були явища рефлюкс-ентериту, отримували 3 цього приводу консервативне лікування. У хворих, яким формували інвагінаційний ілеотрансверзоанастомоз, не спостерігалось проявів рефлюкс-ентериту та, відповідно, вони не отримували консервативне лікування.

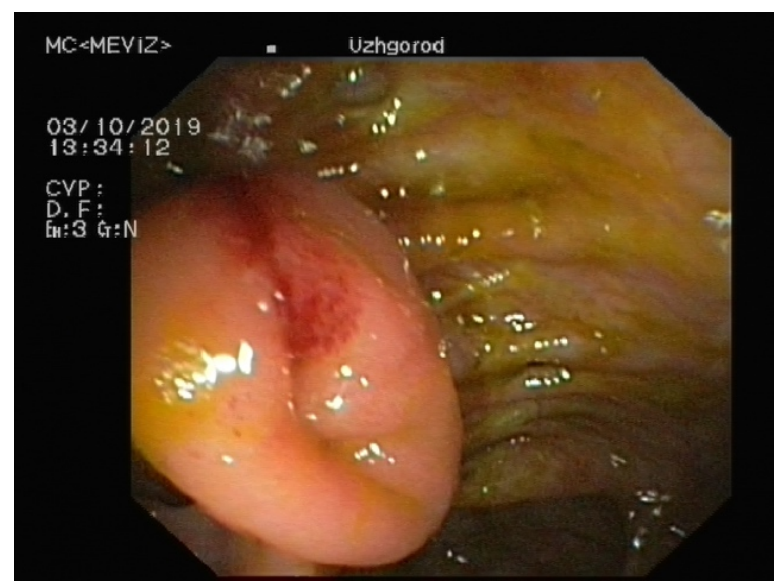

Рис. 2. Ендофото інвагінаційного ілеотрансверзоанастомозу у паціснта на контрольній фіброколоноскопії (через 6 місяців після операції)

Обговорення результатів. Таким чином, можна стверджувати, що інвагінаційні ілеотрансверзоанастомози переймають на себе функцію ілеоцекального клапана.

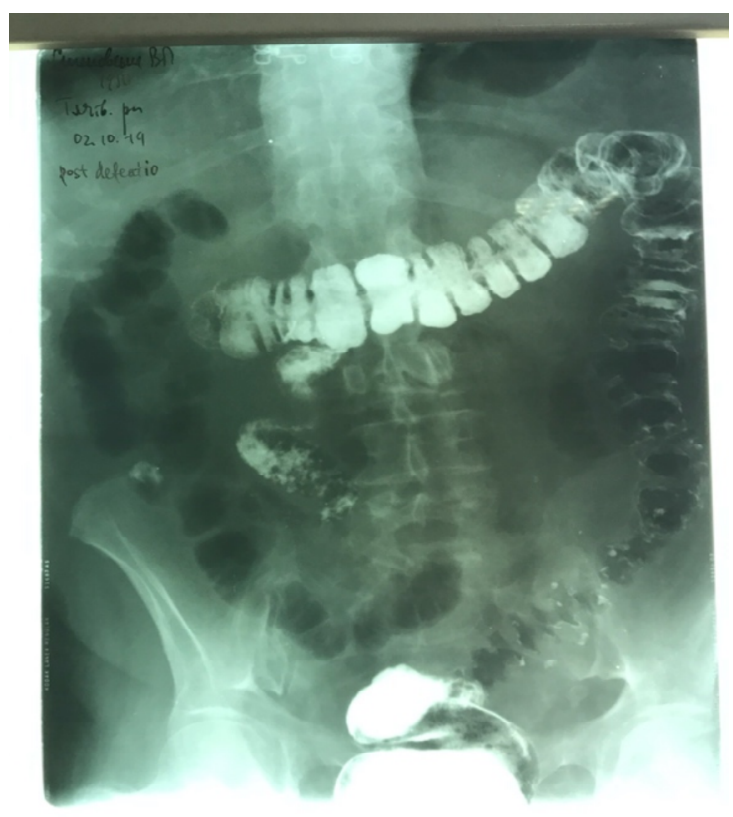

Рис. 3. Рентгенограма під час контрольної іригографії після формування інвагінаційного ілео-трансверзоанастомозу (через 6 місяців після операції)

Серед чисельних способів формування ілеотрансверзоанастомозу слід виділити основні два варіанти: а) прямі - по типу «кінець в кінець», «кінець в бік», «бік в бік» - вони передбачають просте з'єднання кишок; б) клапанні, які передбачають формування замикаючої функції для попередження рефлюкса товстокишкового вмісту у тонку кишку 3 імітацією Баугінієвої заслінки [3].

Правила формування прямих анастомозів універсальні для всіх кишкових співгирл. Як правило, використовують двохрядний шов. Перший ряд - серозно-м'язовий, другий - також одиничний внутрішньовузловий шов через усі шари. При цьому «торець» ободової кишки повинен бути надійно ушитий за допомогою кисетних або апаратно-кисетних швів. Ще одна вимога - необхідно уникати формування «сліпого мішка» проксимальніше анастомозу. До основного недоліку прямих анастомозів відносять рефлюкс-ентерит, частота появи якого спостерігається приблизно у $30 \%$ хворих [3].

Клапанні анастомози беруть свій початок від кінцево-бокових інвагінаційних співгирл по Мейларду і відрізняються між собою від поздовжнього розсічення товстої кишки (по В.П. Войленко) до поперечного розрізу останньої (по Я.В. Вітебському) [3,5]. Наша методика більш проста в технічному виконанні, інвагінація 3-4 см кишки в просвіт товстої кишки на 
ширину тонкої кишки із фіксацією однорядними внутрішньовузловими швами без захоплення у шов слизової оболонки [3].

Окремі автори пропонують створювати інвагінаційні клапани в тонкій кишці в безпосередній близькості від ілео-трансверзоанастомозу (І.У. Свистонюк) [3]. Але, на наш погляд, при ОРОК відкривати просвіт кишки це додаткова травма, а також можливість контамінації мікрофлорою кишківника і зменшення надійності міжкишкового шва.

При визначенні оптимальних кордонів резекції товстої кишки важливо враховувати також локалізацію іiі анатомічних та функціональних сфінктерів. При формуванні як первинних анастомозів, так і реконструктивно-відновних операцій, будь-яка перепона для нормального пересування кишкового вмісту може призвести до підвищення внутрішньокишкового тиску (ВКТ), що може зіграти негативну роль в плані розвитку неспроможності швів анастомозу $[9,13]$.

Йде мова про те, що анастомоз повинен створюватись на відрізку товстої кишки, де, ймовірно, клапанів немає. При цьому інвагінаційний тонкотовстокишковий анастомоз може створюватись у будь-якому відділі ободової кишки.

На наш погляд, покращити інтегральні показники надання медичної допомоги хворим на ОРОК могли б організаційні заходи, зокрема регламентування певного обсягу допомоги, спрямованого на збереження життя пацієнтів при механічній кишковій непрохідності на рівні центральних районних та міських лікарень шляхом впровадження правобічної геміколектомії 3 інвагінаційним ілеотрансверзоанастомозом в запропонованій модифікаціï.

Висновки. Запропонований нами інвагінаційний однорядний ілео-трансверзоанастомоз надійно відновлює прохідність кишківника, перешкоджає розвитку рефлюкс-ентериту, технічно простий у виконанні і може бути рекомендованим до практичного використання при обструктивному раку ободової кишки.

\section{References:}

1. Mykhailovych YuI, Zvirych VV, Kolesnik OO. Kolorektalnyi skryninh yak konsensusne vyrishennia problemy mistsevo-poshyrenoho raku tovstoi ta priamoi kyshky v Ukraini. Dyskusii i pytannia. Klinicheskaja onkologija. 2017; 4(28):13-18. [In Ukrainian].

2. Siegel RL, Miller KD, Fedewa SA, Ahnen DJ, Meester RG, Barzi A, et al. Colorectal cancer statistics, 2017. CA: A cancer journal for clinicians. 2017; 67(3):177-93. DOI: https://doi.org/10. $3322 /$ caac. 21395

3. Belyj VJa, Rusin VI, Fomin PD, Chobej SM, Cema EE. Ocherki hirurgii raka tolstoj kishki. Uzhgorod: Karpaty; 2020. P.243. [In Russian].

4. Shogan BD, Carlisle EM, Alverdy JC, Umanskiy K. Do we really know why colorectal anastomoses leak? Journal of Gastrointestinal Surgery. 2013;
17(9):1698-1707. DOI: https://doi.org/10.1007/ s11605-013-2227-0

5. Rusyn VI, Chobei SM, Rusyn AV, Boldizhar OO, Ihnat VI. Tovstokyshkova neprokhidnist pukhlynnoho henezu. Uzhhorod; 2010. P.316. [In Ukrainian].

6. Matviichuk BO, Matviichuk OB, Fetsych MT. Aktualni problemy nevidkladnoi khirurhii kolorektalnoho raku. Shpytalna khirurhiia. Zhurnal imeni LIa Kovalchuka. 2015; 2:20-23. [in Ukrainian].

7. Alekperov SF, Pugav AV, Kalachev OA, Achkasov EE, Melnikov PV, Kanner DYu. Diagnostika i hirurgicheskoe lechenie obturatsionnoy opuholevoy tolstokishechnoy neprohodimosti. Hirurgiya. 2012; 11:38-44. [In Russian].

8. Aliev SA, Aliev ES. Evolyutsiya taktiki i metodov hirurgicheskogo lecheniya opuholevoy tolstokishechnoy neprohodimosti. Hirurgiya. 2013; 4:92-98. [In Russian].

9. Chadi SA, Fingerhut A, Berho M, DeMeester SR, Fleshman JW, Hyman NH, et al. Emerging trends in the etiology, prevention, and treatment of gastrointestinal anastomotic leakage. J Gastrointest Surg. 2016; 20(12):2035-51. DOI: https://doi.org/ $10.1007 / \mathrm{s} 11605-016-3255-3$

10. Aslar AK, Özdemir S, Mahmoudi H, Mehmet AK. Analysis of 230 Cases of Emergent Surgery for Obstructing Colon Cancer - Lessons Learned. J Gastrointest Surg. 2011; 15:110-119. https://doi.org/10.1007/s11605-010-1360-2.

11. Rusyn VI, Chobei SM, Rusyn AV, Filip SS, vynakhidnyky; Rusyn VI, patentovlasnyk. Sposib stvorennia ileo-transverzo-anastomozu. Patent Ukrainy № 98084582. 2000; hrud, 15. [In Ukrainian].

12. The jamovi project (2020). jamovi. (Version 1.2.) [Computer Software].

13. Belyj VJa, Rusin VI, Fomin PD, Zhovtonozhko AI. Ocherki hirurgii ostroj kishechnoj neprohodimosti. Uzhgorod: Karpaty; 2019. P.284. [In Russian].

УдК 616.345-006.6:616.34-007.272:616.345/.348089.86

\section{ГЕМИКОЛЭКТОМИЯ ПРИ ОБСТРУКТИВНОМ РАКЕ ПРАВОЙ ПОЛОВИНЫ ОБОДОЧНОЙ КИШКИ}

\section{В.И. Русин, С.М. Чобей, А.А. Дутко}

Ужсгородский национальный университет, медищинский факультет, кафедра хирургических болезней, г. Ужгород, Украина,

ORCID ID: 0000-0001-5688-9951,

ORCID ID: 0000-0002-1231-8169,

ORCID ID: 0000-0002-4063-8194,

e-mail:dutko.sasha93@gmail.com

Резюме. Цель исследования. Для улучшения результатов лечения больных на обструктивный рак правых отделов толстой кишки разработать и внедрить в клиническую практику инвагинационный илео-трансверзоанастомоз. 
Материалы и методы. В хирургическом отделении №2 Закарпатской областной клинической больницы им. Андрея Новака за 2015-2019 гг. нами прооперировано 94 больных с обструктивным раком правых отделов толстой кишки. У 39 больных исполнена правосторонняя гемиколэктомия с двухрядным илео-трансверзоанастомозом, у 55 - по бесконтактной изолированной методике с инвагинационным илео-трансверзоанастомозом в нашей модификации.

Результаты исследования. При использовании двухрядного шва у 2 пациентов наступила несостоятельность анастомоза. При формировании инвагинационного илео-трансверзоанастомоза осложнений не было. На контрольной фиброколоноскопии инвагинационная культя подвздошной кишки перистальтировала в просвет поперечно-ободочной кишки. На ирригоскопии рефлюкс-энтерита не было. Можно утверждать, что инвагинационные илеотрансверзоанастомозы берут на себя функцию илеоцекального клапана. При определении границ резекции толстой кишки важно учитывать локализацию ее сфинктеров. Любая преграда для продвижения кишечного содержимого может привести к повышению внутрикишечного давления и развития несостоятельности анастомоза. Инвагинационный анастомоз можно формировать в любом отделе ободочной кишки.

Выводы. Предложенный нами инвагинационный однорядный илео-трансверзоанастомоз надежно возобновляет проходимость кишечника, препятствует рефлюкс-энтериту, прост в исполнении и может быть рекомендован для практического использования при обструктивном раке ободочной кишки.

Ключевые слова: илео- трансверзоанастомо3, рак толстой кишки, кишечная непроходимость, гемиколэктомия.

UDC 616.345-006.6:616.34-007.272:616.345/.348089.86

\section{HEMICOLECTOMY IN OBSTRUCTIVE CANCER OF THE RIGHT HALF OF THE COLON}

V.I. Rusyn, S.M. Chobey, O.O. Dutko

Surgical Diseases Chair of Medical Faculty of Uzhgorod National University, Uzhgorod, Ukraine,

ORCID ID: 0000-0001-5688-9951,

ORCID ID: 0000-0002-1231-8169,

ORCID ID: 0000-0002-4063-8194,

e-mail:dutko.sasha93@gmail.com

Abstract. The aim of the study is to improve the results of treatment in patients with obstructive cancer of the right colon and to develop and implement into clinical practice an invaginational ileotransverse anastomosis.

Materials and methods. In the Surgical Department №2 of Regional Clinical Hospital named after
Andrii Novak in the period 2015-2019 years 94 patients with obstructive colon cancer of the right colon underwent surgical treatment. 39 patients underwent right hemicolectomy with two-row "side by side" type ileotransverse anastomosis, for 55 patients a non-contact isolational technique with one-row invaginational ileotransverse anastomosis in our modification was performed. The concept of this technique is from the beginning of intervention to ensure the maximally blocking the main ways of tumor metastases - on the intestinal wall, hematogenous, lymphogenic and contact ways. After revision the tumor must be left "alone" - do not palpate it until colon resection. Ileotransverse anastomosis is performed due to Ukrainian patent \#98084582. After resection, a purse-string suture is made on the end of ileum with a long ligature, which is hold under tension, so contamination of abdominal cavity by microflora is excluded. The distal $2-3 \mathrm{~cm}$ of ileum should be cleared from mesentery. The free end of ileum is sewn to transverse colon "end to side" under the tenia libera with one-row of serous-muscular sutures. The colon is cut along tenia to the width of the ileum diameter. Through this hole a puncture is made in tenia libera with the purse-string suture, which helps to invaginate the ileum into the colon lumen. After, serous-muscular sutures are sewn on the anterior part of anastomosis. The untied purse-string suture is deleted, which leads to opening of the ileum lumen.

Results and discussion. After right hemicolectomy with a two-row "side by side" anastomosis anastomotic leakage was noticed in 2 patients $(5,1 \%)$. After the formation of one-row "end to side" invaginational ileotransverse anastomosis no compilcations were noticed. On the control colonoscopy the stump of the ileum peristalted through intestinal wall into the transverse colon lumen. On barium enema reflux-enteritis was not observed. It can be argued, that invaginational ileotransverse anastomoses take over the function of the ileocecal valve. In our opinion, opening the lumen of the bowel is a possibility of contamination of abdomen by intestinal microflora and decreasement in reliability of an intestinal anastomosis.

In determining the optimal borders of colon resection, it is important to consider its sphincters localization. In the formation of anastomoses any obstacle for moving of intestinal contents may lead to increasement of intracolonic pressure, which can play a negative role in anastomotic leakage. The anastomosis should be formed on a colon section where are probably no sphincters. At the same time, one-row invaginational ileotransverse anastomosis can be performed in any part of the colon.

Conclusions. The offered one-row invaginational ileotransverse anastomosis reliably restores the intestinal patency, prevents the development of reflux-enteritis, is technically easy to perform and can be recommended for practical use in patients with obstructive colon cancer.

Keywords: ileotransverse anastomosis, colon cancer, intestional obstruction, hemicolectomy. 